\title{
Regime Types or Party Systems: What Matters More For Political Instability In The Developing World?
}

\author{
M. Moniruzzaman, $\mathrm{PhD}$, Associate Professor \\ Department of Political Science, International Islamic University Malaysia \\ Gombak, Kuala Lumpur 53100, Malaysia \\ E-mail: mmzaman@ iium.edu.my
}

Received: June 4, 2015 Accepted: June 30, 2015 Published: October 4, 2015

doi:10.5296/iss.v3i2.7743 URL: http://dx.doi.org/10.5296/iss.v3i2.7743

\begin{abstract}
Political stability is desired by every state. But is it contingent upon regime types or party systems? Existing studies on political stability suggest that regimes such as authoritarianism, democracy, and dictatorship and their variants have variously influenced political stability. Some have proved to be friendly with political stability in certain countries, while counterproductive for some other. However, the existing literature has exclusively focused on regime types alone neglecting the factor of party systems. This article argues that not only regime types but party systems also influence political stability. Based on data from Asia, Africa and Latin America this article examines the following four assumptions. Firstly, absolute monarchy and absolute authoritarianism together with no or one party system generally maintain political stability. Secondly, constitutional monarchies together with multiparty system generally maintain political stability. Thirdly, presidentialism together with dominant party system generally maintains political stability. And finally, parliamentarianism together with multi-party system is generally negatively related with political stability.
\end{abstract}

Keywords: political instability, regime, party system, developing world 


\section{Introduction}

In today's globalized world no country is foreign to each other due to borderless mass communication channels and media. Yet countries like New Zealand, Norway, Japan and Canada hardly make headlines in global news except during national regular elections or if they are struck by natural calamity. By contrast countries like Egypt, Indonesia, Pakistan and Venezuela make daily global headline news. These news are not of national regular elections but of daily political violence across society. A clear pattern that is observable around the world is that highly developed countries hardly make political headlines on political violence and crisis while many countries in the developing world make political headlines on that almost on a daily basis. Naturally, this phenomenon warrens questions such as why developed countries do not experience political violence and crisis on a regular basis, and why many of the developing countries experience it on a daily basis? The questions can be posed in a different way- why developed countries are politically stable while developing countries in general are not?

A global survey on these questions is a huge task due to variation in political, economic, social, cultural and other factors particular to a given country. As such various explanations can be offered in answering these questions, and yet these explanations may not be universally applicable to countries across the developed and developing worlds. Alternatively, in answering these questions the approaches adopted might be different. Instead of analyzing factors for instability one may address factors for stability in the developed world and factors for instability in the developing world which may result in different conclusions. Due to such problems it is easier to take similar country approach in comparative analysis.

This article focuses on political instability in the developing world during the past one decade. As such it includes basically countries in Asia, Africa and Latin America that are grouped as 'developing' by the World Bank. The objective is to see whether regime type or party system that accounts more for political instability in these countries.

\section{Defining Political Instability}

'Political instability' is a very fluid concept that can be defined in many ways depending on the focus and level of study. Margolis (2010:332) has defined the concept by defining 'stability' instead saying "political stability is the degree to which the formal and informal coincide... when the formal roles and structures set by authority match those constructed by informal social interaction, an object is stable. When either set of roles or structures change so they conflict, an object is unstable to some degree...perfect stability is total correlation; perfect instability, the total absence of correlation."

In operationalizing the concept various perspectives are considered. Taking a macro and institutional perspective, Political Instability Task Force (PITF) has defined political instability in terms of 'state failure' events (Marshall, 2008). Here instability is analyzed by revolutionary war, ethnic war, adverse regime change, and genocide or politicide. It means presence of these factors is indicative of political instability. Revolutionary wars are "episodes of violent conflicts between governments and politically organized groups 
(political challengers) that see to overthrow the central government, to replace its leaders, or to seize power in one region." Ethnic wars are defined as "episodes of violent conflict between governments and national, ethnic, religious, or other communal minorities (ethnic challengers) in which the challengers seek major changes in their status." Adverse regime changes are shifts in patterns of governance in terms of drastic change in government either by replacement or shift in its nature, breakdown of state structure, or collapse of central authority. And finally genocide and politicide are events involving 'the promotion, execution, and/or implied consent of sustained policies by governing elites or their agents or in the case of civil war, either of the contending authorities that result in the deaths of a substantial portion of a communal group or politicized noncommunal group."

A second approach to define political instability from macro perspective is to focus on the performance of the state as an institution. This approach is known as 'fragility' approach and assessed by Fragile States Index (FSI) using 12 variables which are Demographic Pressure, Internally Displaced Persons, Group Grievance, Human Flight and Brain Drain, Uneven Economic Development, Poverty and Economic Decline, State Legitimacy, Public Services, Human Rights and Rule of Law, Security Apparatus, Factionalized Elites, External Intervention. The lower the performance of a state in managing these factors higher the fragility of the state. A higher fragility leads to higher political instability. So the basic issue here is the degree of system performance.

A third approach is used by Peace and Conflict Instability Ledger (PCIL) to define political instability through assessing the level of Peace and Conflict in a society which is measured using five variables namely Regime Consistency, Infant Mortality, Economic Openness, Militarization, and Neighbourhood War. Lower the government performance in the se higher the prospect of conflict leading to state instability.

However, political instability is also defined and assessed from micro perspective. This perspective looks into instability from more societal and everyday life perspective. This micro perspective takes into consideration indicators such as Coup, Assassination, General strikes, Government crisis, Purge, Riot/violence, Anti-government demonstration, Death from political violence, and Political strikes (Hibbs, 1973). No large-scale research has been conducted using these indicators.

\section{Literature Review}

Comparative politics literature is inundated with studies on the question of the merits of regime types and their varieties. Studies on political regime became a fashion in the 1950s and 1960s (Gasiorowski, 1990). Earlier trend in the study focused on comparative merits and performance of regime types such as totalitarianism (Arendt, 1951; Friedrich \& Brzezinski, 1965), authoritarianism (Hadenius \& Teorell, 2006; Linz 1978; O’Donnell, 1973; Stepan, 1973), and democracy (Lerner, 1958; Lipset, 1960, Huntington, 1968, Hanson et al., 2005). Increasingly, the trend settled with the study of democracy and its variants- presidential and parliamentary, on the question of which variants offer more stability than the other (Skaaning, 2006; Snyder \& Mahoney, 1992). 
A dominant view in comparative literature is that presidential regime type is generally and inherently less stable than parliamentary regime type. An important reason advanced in support of the argument is that separation of power in the presidential system makes presidents of the developing countries less powerful in controlling the other organs of government which deprives the presidents of exercising their tendency to concentrate power in their personality or close-knit elite circle. So the presidents tend to resort to extra-constitutional exercise of power leading to dissatisfaction of various interest groups causing regime change or political resistance and instability. Linz (1990a) argues that inflexibility, rigidity and 'winner-takes-all' in elections create dissatisfaction and political exclusion leading to political instability. In contrast, Linz (1990b) and Di Palma (1990) argue that accommodation, flexibility, greater accountability and greater representational virtues make parliamentary regime more politically stable.

Lijphart (1999) in his study on Patterns of Democracy concluded that consensus regime, which according to him is a better version of Westminster or parliamentary type, is inherently more stable due to the balance of power being inherently more consensual. This argument indirectly goes in favour of parliamentary regime and against presidential regime. Along the same line and in favour of parliamentary regime Lijphart (1977) advanced the theory of consociational democracy arguing for sound political stability.

Another important study conducted by Przeworski et el., (2000) focusing on a different set of variables concluded that presidential regimes have greater tendency towards political instability than parliamentary regimes irrespective of the level of wealth and per capita income. In contrast, parliamentary regimes are less instable, and less likely to experience breakdown irrespective of the level of per capita income and wealth. However, Power and Gasiorwski (1997) and Gasiorwski and Power (1998) in their studies have found that among consolidated presidential regimes relationship between the choice of presidential regime and regime instability and breakdown is insignificant.

An overarching problem with these studies is that they analyse the essential internal characteristics of the regimes- presidential and parliamentary, in general without considering an important variable- the party system. Either of these regimes prescribes for and operates under multi-party system, but they also tend to feel comfortable with various party systems in the spectrum such as one party, one party dominant or two party systems. These studies do not consider whether these various party systems can have any effect on political stability or instability.

Recently, however, some studies have started to focus on this aspect. For instance, Stephan and Skach (1993) had looked at all democracies that emerged after 1945, and by examining the relationship between party system and regime type they found out that presidential regimes are more unstable than parliamentary regimes. A more authoritative study on the issue along the same line is done by Shugart and Carey (1992). In their study entitled Presidents and Assemblies the authors argue that it is not presidentialism per se that is problematic, rather it is the faulty institutional design such as over-empowering the president and inappropriate party systems that tend to cause political and regime instability. Lawrence 
(2000) has argued that it is the legacy of past authoritarian rule not the regime as such that negatively affect political stability under presidential regime. Seifu (2009) has found in the case of Africa that presidential regimes with British colonial legacy and better economic performance have experienced less political instability in the form of regime change. However, autocratic regimes regardless of colonial past seem to have enjoyed longer stability in terms of regime survival.

Political stability and regime types have also been studied more recently from economic, foreign aid (Caselli, 2011), health (Davies, 2014) and political participation (Ekman, 2019; Sottilotta, 2013) perspectives. These studies look more into external non-political factors that may contribute to political stability or instability directly or indirectly. However, despite certain evidence of influencing roles, these factors are not proven to be stronger compared with political institutional factors such as parties and types of government.

\section{Data and Method}

The data for this research are sourced from Fragile State Index (FSI) and Peace and Conflict Instability Ledger (PCIL) data bank (Gurr et al., 2001; Hewitt et al., 2012) over the past one decade. These two institutions maintains large amount of data on all the countries focusing on factors that cause or have potential to cause political instability in a country. The concept of 'developing countries' in this research is defined as countries which fall outside the lis t of OECD (Organization for Economic Cooperation and Development) countries categorized as highly developed industrial economies. The FSI index includes the following 12 indicators: Demographic Pressure, Internally Displaced Persons, Group Grievance, Human Flight and Brain Drain, Uneven Economic Development, Poverty and Economic Decline, State Legitimacy, Public Services, Human Rights and Rule of Law, Security Apparatus, Factionalized Elites, External Intervention. And the PCIL ledger includes the following six indicators: Regime Consistency, Infant Mortality, Economic Openness, Militarization, and Neighbourhood War.

The data from both the sources are analyzed using descriptive statistics and cross-country comparison. There are four basic assumptions adopted in this study. Firstly, absolute monarchy and absolute authoritarianism together with no or one party system generally maintain political stability. Secondly, constitutional monarchies together with multiparty system generally maintain political stability. Thirdly, presidentialism together with dominant party system generally maintains political stability. And finally, parliamentarianism together with multi-party system is generally negatively related with political stability.

\subsection{The Data}

The first assumption is that absolute monarchy and absolute authoritarianism to gether with no or one party system generally maintain political stability. In the category of absolute monarchies there are six countries namely Bhutan, Brunei, Oman, Qatar, Saudi Arabia and Swaziland. These countries have active monarchies which do not allow political parties. Table 1 shows FSI and PCIL scores for these countries. 
Table 1. Monarchy regimes

\begin{tabular}{llccc}
\hline Country & $\begin{array}{c}\text { Fragile States } \\
\text { Index score } \\
2006\end{array}$ & $\begin{array}{c}\text { Fragile States } \\
\text { Index score } \\
-2014\end{array}$ & $\begin{array}{c}\text { Peace and Conflict } \\
\text { Instability Ledger score } \\
\text { 2012 }\end{array}$ \\
\hline 1 & Brunei & 71.2 & 63.6 & 0.0 \\
2 & Oman & 43.8 & 53.1 & 0.5 \\
3 & Qatar & 53.6 & 48.9 & 0.3 \\
4 & Saudi Arabia & 77.2 & 73.1 & 0.5 \\
5 & Swaziland & 81.3 & 85.8 & 1.0 \\
6 & Bhutan & -- & -- & -- \\
\hline
\end{tabular}

Source: compiled by the author from FSI and PCIL indices.

In the category of absolute authoritarianism there are seven countries. This authoritarianism is run by party rather than an individual. The countries include Cuba, North Korea, Eritrea, Laos, China, Sahwari Republic and Vietnam. Table 2 show FSI and PICL scores for these countries.

Table 2. Authoritarian regimes

\begin{tabular}{llccc}
\hline & Country & \multicolumn{2}{c}{ Fragile States Index score } & $\begin{array}{c}\text { Peace and Conflict } \\
\text { Instability Ledger score } \\
\end{array}$ \\
& 2006 & 2014 & 2012 \\
\hline 1 & Cuba & 81.9 & 70.8 & 0.3 \\
2 & North Korea & 97.3 & 94.0 & 4.2 \\
3 & Eritrea & 83.9 & 95.5 & 5.4 \\
4 & Laos & 87.9 & 84.3 & 2.9 \\
5 & China & 82.5 & 79.0 & 0.9 \\
6 & Sahrawi Republic & -- & -- & -- \\
7 & Vietnam & 78.6 & 72.7 & 0.6 \\
\hline
\end{tabular}

Source: compiled by the author from FSI and PCIL indices.

The second assumption of the research is that constitutional monarchies together with multiparty system generally maintain political stability. There are 15 countries and regions in this category. These are Andorra, Antigua and Barbuda, Bahamas, Barbados, Belize, Cambodia, Jamaica, Lesotho, Malaysia, Papua New Guinea, Saint Kitts and Nevis, Saint Lucia, Saint Vincent and the Grenadines, Solomon Islands, Thailand, and Tuvalu. Table 3 presents the FSI and PCIL scores for these countries. 


\section{Macrothink}

Issues in Social Science

ISSN 2329-521X

2015, Vol. 3, No. 2

Table 3. Constitutional monarchies and multi-party system

\begin{tabular}{llccc}
\hline & Country & \multicolumn{2}{c}{ Fragile States Index score } & \multicolumn{2}{c}{$\begin{array}{c}\text { Peace and Conflict } \\
\text { Instability Ledger score }\end{array}$} \\
\cline { 3 - 4 } & 2006 & 2014 & 2012 \\
\hline 1 & Cambodia & 85.0 & 88.5 & 7.3 \\
2 & Lesotho & 81.2 & 78.6 & 6.8 \\
3 & Malaysia & 66.1 & 66.2 & 1.8 \\
4 & Papua New Guinea & 84.6 & 84.1 & 9.2 \\
5 & Thailand & 74.9 & 77.0 & 4.2 \\
6 & Morocco & 76.5 & 74.4 & 1.9 \\
7 & Jordan & 77.0 & 76.7 & 4.3 \\
\hline
\end{tabular}

Source: compiled by the author from FSI and PCIL indices.

The third assumption of the study is that presidentialism together with dominant party system generally maintains political stability. There are 89 countries that have presidential system of government. This category includes full and semi-presidential systems, allows more than one party but a single party dominates politics. Out of 89 there are 44 countries that have a dominant party system. The president in this type of states is more inclined towards authoritarian characteristics due to charismatic, military or autocratic past or tendencies. Of 44, 18 had dominant party system in the past. Table 4 present the FSI and PCIL scores for these countries.

And finally, the last assumption of the study maintains that parliamentarianism together with multi-party system is generally negatively related with political stability. There are 24 countries in this category. These are Albania, Bangladesh, Bosnia-Herzegovina, Bulgaria, Dominica, Ethiopia, Hungary, India, Iraq, Kosovo, Kyrgyzstan, Lebanon, Libya, Mauritius, Moldova, Mongolia, Montenegro, Nepal, Pakistan, Samoa, Somalia, Trinidad and Tobago, Turkey, and Vanuatu. Table 5 presents the FSI and PCIL scores for these countries.

Table 4. Presidential regimes with dominant party system

\begin{tabular}{|c|c|c|c|c|c|}
\hline & \multirow[t]{2}{*}{ Country } & \multicolumn{2}{|c|}{ Fragile States Index score } & \multirow{2}{*}{$\begin{array}{l}\text { Peace } \\
\text { Instability } \\
2012\end{array}$} & \multirow{2}{*}{$\begin{array}{l}\text { and Conflict } \\
\text { Ledger score }\end{array}$} \\
\hline & & 2006 & 2014 & & \\
\hline 1 & Algeria & 77.8 & 78.8 & & 3.8 \\
\hline 2 & Angola & 88.3 & 87.4 & & 9.1 \\
\hline 3 & Armenia & 75.5 & 71.3 & & 9.5 \\
\hline 4 & Azerbaijan & 81.9 & 77.8 & & 1.6 \\
\hline 5 & Botswana & 66.9 & 64.5 & & 6.4 \\
\hline 6 & Brazil & 63.1 & 61.4 & & 5.6 \\
\hline
\end{tabular}




\begin{tabular}{|c|c|c|c|c|}
\hline 7 & Burkina Faso & 89.7 & 89.0 & 10.5 \\
\hline 8 & Cameroon & 88.4 & 93.1 & 8.7 \\
\hline 9 & Chad & 105.9 & 108.7 & 13.4 \\
\hline 10 & Congo, Rep of & 93.0 & 89.6 & 29.8 \\
\hline 11 & Costa Rica & 49.6 & 48.5 & 0.6 \\
\hline 12 & Djibouti & 80.3 & 87.1 & 23.5 \\
\hline 13 & Egypt & 89.5 & 91.0 & 3.8 \\
\hline 14 & Equatorial Guinea & 84.0 & 85.3 & 2.6 \\
\hline 15 & Gambia & 74.0 & 83.1 & 2.5 \\
\hline 16 & Gabon & 73.6 & 72.2 & 11.1 \\
\hline 17 & Guinea & 99.0 & 102.7 & 7.9 \\
\hline 18 & Indonesia & 89.2 & 76.8 & 5.2 \\
\hline 19 & Kazakhstan & 71.9 & 68.5 & 1.0 \\
\hline 20 & Kenya & 88.6 & 99.0 & 11.5 \\
\hline 21 & Mexico & 73.1 & 71.1 & 3.8 \\
\hline 22 & Mozambique & 74.8 & 85.9 & 15.2 \\
\hline 23 & Myanmar & 96.5 & 94.3 & 4.2 \\
\hline 24 & Namibia & 70.7 & 71.5 & 6.4 \\
\hline 25 & Nigeria & 94.4 & 99.7 & 20.7 \\
\hline 26 & Philippines & 79.2 & 85.3 & 4.3 \\
\hline 27 & Rwanda & 92.2 & 90.5 & 4.6 \\
\hline 28 & Seychelles & 71.3 & 63.7 & -- \\
\hline 29 & Senegal & 66.1 & 82.8 & 8.0 \\
\hline 30 & South Africa & 55.7 & 66.6 & 5.9 \\
\hline 31 & South Sudan & 108.4 & 112.9 & -- \\
\hline 32 & Sudan & 112.3 & 110.1 & 4.5 \\
\hline 33 & Syria & 88.6 & 101.6 & 1.1 \\
\hline 34 & Tajikistan & 87.7 & 84.6 & 7.3 \\
\hline 35 & Tanzania & 78.3 & 80.8 & 9.5 \\
\hline 36 & Togo & 88.3 & 87.8 & 5.4 \\
\hline 37 & Turkmenistan & 86.1 & 78.2 & 1.3 \\
\hline 38 & Uganda & 94.5 & 96.0 & 10.7 \\
\hline 39 & Uruguay & 41.2 & 37.9 & 0.8 \\
\hline 40 & Uzbekistan & 94.4 & 86.3 & 1.1 \\
\hline 41 & Venezuela & 81.2 & 76.7 & 3.1 \\
\hline 42 & Yemen & 96.6 & 105.4 & 6.9 \\
\hline 43 & Zambia & 79.6 & 86.2 & 12.3 \\
\hline 44 & Zimbabwe & 108.9 & 102.8 & 12.0 \\
\hline
\end{tabular}

Source: compiled by the author from FSI and PCIL indices. 
Table 5. Parliamentary Regimes with Multi-Party System

\begin{tabular}{|c|c|c|c|c|}
\hline & \multirow[t]{2}{*}{ Country } & \multicolumn{2}{|c|}{ Fragile States Index score } & \multirow{2}{*}{$\begin{array}{c}\text { Peace and Conflict } \\
\text { Instability Ledger score } \\
2012 \\
\end{array}$} \\
\hline & & 2006 & 2014 & \\
\hline 1 & Albania & 68.6 & 63.6 & 2.2 \\
\hline 2 & Bangladesh & 96.3 & 92.8 & 12.0 \\
\hline 3 & Bosnia-Herzegovina & 88.5 & 75.9 & 1.6 \\
\hline 4 & Bulgaria & 62.1 & 54.4 & 2.0 \\
\hline 5 & Dominica & 85.0 & 73.5 & 4.8 \\
\hline 6 & Ethiopia & 91.9 & 97.9 & 21.2 \\
\hline 7 & Hungary & 46.7 & 48.3 & 0.3 \\
\hline 8 & India & 70.4 & 76.9 & 9.6 \\
\hline 9 & Iraq & 409.0 & 102.2 & 15.5 \\
\hline 10 & Kosovo & - & - & - \\
\hline 11 & Kyrgyzstan & 93.0 & 83.9 & 7.4 \\
\hline 12 & Lebanon & 80.5 & 86.9 & 4.6 \\
\hline 13 & Libya & 68.5 & 87.8 & 0.9 \\
\hline 14 & Mauritius & 41.9 & 46.1 & 0.8 \\
\hline 15 & Moldova & 82.5 & 75.1 & 2.3 \\
\hline 16 & Mongolia & 58.4 & 58.1 & 1.3 \\
\hline 17 & Montenegro & 55.6 & 55.7 & 1.9 \\
\hline 18 & Nepal & 95.4 & 91.0 & 11.1 \\
\hline 19 & Pakistan & 103.1 & 103.0 & 20.8 \\
\hline 20 & Samoa & 73.8 & 69.3 & - \\
\hline 21 & Somalia & 105.9 & 112.6 & 17.6 \\
\hline 22 & Trinidad and Tobago & 67.6 & 61.3 & 1.4 \\
\hline 23 & Turkey & 74.4 & 74.1 & 6.1 \\
\hline 24 & Vanuatu & - & - & - \\
\hline
\end{tabular}

Source: compiled by the author from FSI and PCIL indices.

\section{Discussion and Analysis}

The data in the foregoing section rest on two assumptions. Firstly, if the fragility score of a country is high on the index then the country has higher rate of political instability. Secondly, if a country scores high on Peace and Conflict Instability Ledger index the country has high rate of political instability.

The data show some confirming and non-confirming tendencies to the assumptions proposed. It was assumed that absolute monarchies with no political party generally maintain political stability. On Fragility Index the six absolute monarchies fared better, as shown on Table 1, compared to constitutional monarchies, authoritarian, presidential and parliamentary regimes. And on PCIL score they even come close to no instability, which is much higher compared with all other regime types. 
Secondly, the data on Table 3 show that most of the seven constitutional monarchies with multi-party system have higher level of political instability both on Fragility and PCIL indices. Only one country (Malaysia) has the lowest instability score ( $66.1 \& 1.8$ compared to the highest $85.0 \& 9.2$ ). This result, therefore, does not support the assumption presented that constitutional monarchies with multi-party system generally maintains political stability.

Thirdly, the data on Table 2 show that the seven authoritarian regimes score relatively high on the Fragility Index (highest 95.6, lowest 70.8) suggesting higher rate of instability, but scored relatively low of PCIL index (highest 5.4, lowest 0.3) suggesting lower rate of instability. However, on an average the authoritarian regimes apparently enjoy less political instability than constitutional monarchies. But they are more unstable than absolute monarchies. Therefore, the data supports the assumption that absolute authoritarianism together with no or one party system generally maintains political stability.

Fourth, the data on Table 4 show that on Fragility Index out of 44 presidential regimes with dominant party system two countries scored below 50.0, no country scored between 51-60, five countries scored between 61-70, nine countries scored between 71-80, 13 countries scored between 81-90, seven countries scored between 91-100, and another seven countries scored above 100. Among these scores the lowest is 37.9 and the highest is 112.9. This means half of the total 44 countries scored between 71-90. And a majority of 29 countries score below 90. This means that most of the countries enjoy less political instability.

On the PCIL index, two countries scored below 1.0, 13 countries scored between 1-5, 14 countries scored between 5.1-9.9, eight countries scored between 10-19.9, and three countries scored above 20. The lowest on the index is 0.6 and the highest is 29.8. This means a majority of 29 countries score below 10 suggesting most of the countries enjoying less political instability. This finding supports the findings of Mainwaring (1993), Mainwaring \& Timothy (1995), Mainwaring \& Shugart (1997) and Shugart \& Carey (1992) that presidentialism with multi-party system has higher tendency towards political instability.

And finally, the data on Table 5 show that on the Fragility Index out of 24 parliamentary regimes with multi-party system two countries scored below 50, three scored between 51-60, three scored between 61-70, five scored between 71-80, three scored between 81-90, three scored between 90-100, and two countries scored above 100. The lowest score is 46.1 and the highest being 102.2. This means eight out of 24 countries scored between 71-90, and slightly more than half of the countries (14) scored below 90, which suggest that lesser number of countries compared with presidential regimes enjoy political stability.

Similarly, on PCIL index two countries scored below 1.0, nine countries scored between 1-5, three countries between 5.1-9.9, four countries between 10-19.9, and two countries scored above 20 . That means only slightly more than half (14) of the total 24 countries scored below 10 suggesting that compared with presidential regimes a lesser number of parliamentary ones enjoy political stability.

In other words, the data on presidential and parliamentary regimes support the assumptions that presidentialism together with dominant party system generally maintains political 
stability, and parliamentarianism together with multi-party system is generally negatively related with political stability. So, in the final analysis it appears that absolute monarchies, and authoritarian regimes with no or one party system, and presidential regimes with a dominant party system generally enjoy less political instability, while parliamentary regimes and constitutional monarchies with multi-party system generally suffer from a higher degree of political instability.

The evidence in this research also indicates that party system matters significantly in political stability and instability. In the case of absolute monarchies where no parties are allowed, they are politically much less unstable. The authoritarian regimes studied here are all one-party system, and they maintain comparatively high political stability. The presidential regimes in this study all maintain dominant party system amid many other parties at work, and majority of the regimes maintains a low degree of political instability. On the other hand, constitutional monarchies and parliamentary republican regimes operate under multi-party system, and both types of regimes experience relatively a higher rate of political instability. Therefore, based on the evidence it is probably safe to conclude that it is not regime but party system that matters more in political stability or instability.

\section{Observations on Indicators}

Indicators are equally most sensitive and important in any large-scale comprehensive survey. In the case of studies such as the present one it is even more sensitive as the universe of cases and samples differ extremely from one another in every aspect- political, economic, geographic and population size, historical past, culture, religion, natural environment and temperament. Therefore, selection of universally applicable indicators that can accurately present the scenario is next to impossible.

Even though in this study FSI and PCIL indices are used, some serious observations regarding these indicators are warranted. What accounts for political instability is not easy to determine but at the same time if an inaccurate indicator is chosen then it may end up with disastrous result. First of all, majority of the countries in the category of developing world are located in Asia, Africa and Latin America. These countries are traditionally and historically conflict-ridden, factionalized and intolerant in group competition. Yet despite these differences, some countries are relatively more well-ordered than the others. For instance, in terms of public service delivery Malaysia is far better off than Brazil, so indicators like group grievance, poverty and economic decline, security apparatus in Malaysia will be better than in Brazil. On the other hand, in terms of cultural traits Brazilian people maintain more aggressive tendency compared with people of Malaysia. In such a situation, assessing regime stability by using these factors in the case of public service decline or failure that may lead to violent political unrest is less appealing.

Secondly, indicators like infant mortality, militarization and neighbourhood war are very much context specific. A country may face a sudden epidemic causing an increase in mortality rate, or a small group of people may initiate political violence locally which does not affect the nation at large in which the government may take repressive measures and 
quickly brings order back- in such cases mortality and militarization indicators may not represent or capture the real situation.

Thirdly, the Fragility and PCIL indices do not necessarily capture more important elements and realities of political instability. Many of the developing countries experience year-round political unrest in the form of anti-government demonstration, nationwide or local political strike, violent pre and post elections campaign and showdown. Bangladesh and Pakistan in Asia, Venezuela in Latin America, and Egypt and Nigeria in Africa are some of the countries where various forms of anti-government demonstration are a commonplace, yet these are not represented in the Fragility and PSCIL indices which are major shortcomings.

And finally, instability measured by PITF using the indicators mentioned earlier also suffers from a serious problem. These indicators only look at a handful of major events and magnitudes disregarding plethora of minor events which are more representative of sustained political instability. For instance, PITF ledger on "Internal War and Government Failure 1955-2013" lists Episodes of Political Instability/State Failure in which for Bangladesh only one instance of Adverse Regime Change (1974-75) is recorded, whereas the country experienced violent regime changes a number of times during 1980s and 1990s as well. More interestingly it does not capture any event of Genocide/Politicide in the country while politicide remained a daily feature of the country's political landscape since 1971 onward.

These shortcomings of the Fragility, PCIL, and PITF indices capture either macro features and major events or adopt inaccurate representation of instability factors. Therefore, it is necessary to look at micro and more direct factors associated with political instability. In this regard, the indicators used by Hibbs (1973) and Margiolis (2010) which include Coup, Assassination, General strikes, Government crisis, Purge, Riot/violence, Anti-government demonstration, death from political violence, and political strikes appear more relevant and appropriate in assessing political instability. A large scale and more comprehensive global study of political instability using these indicators may produce a better understanding of relationship between regime type and political instability.

\section{Conclusion}

Political instability is a common phenomenon in many of the developing countries. A plethora of comparative political studies have been conducted to find out what accounts for political instability. Most of the existing studies have analyzed political regimes such as authoritarianism, dictatorship and democracy, and their variants as units of analysis ignoring a fundamental aspect under which these regimes work which is called party system. This research argues that party system largely accounts for political instability in the developing world.

Using the data sets of Fragile States Index (FIS) and the Peace and Conflict Instability Led ger (PCIL) over the past one decade, this study has analyzed five types of regimes in the developing countries namely absolute monarchical regimes, authoritarian regimes, constitutional monarchical regimes, presidential regimes and parliamentary regimes. By looking at the relationship between these regime types and the party system at work in each 
of these countries this research has indicated that party system matters significantly in political stability and instability. In the case of absolute monarchies where no parties are allowed, they are politically much less unstable. All the authoritarian regimes practice one-party system, and they maintain comparatively high political stability. All the presidential regimes in this study maintain dominant party system amid many other parties at work, and majority of the regimes maintains a low degree of political instability. On the other hand, constitutional monarchies and parliamentary republican regimes operate under multi-party system, and both types of regimes experience relatively higher rate of political instability. Therefore, based on the evidence it is reasonable to conclude that it is not regime type but party system that matters more in political stability or instability.

However one needs to be cautious about the type of indicators to be used in exploring the relationship between regime type, party system and instability. The FSI and PCIL indicators have severe shortcomings as they capture only macro-level and major events as evidence for instability. Besides, some of their indicators are indirect and do not necessarily represent accurate measurement for instability. Therefore, more micro-level and direct indicators such as general strikes, government crisis, riot/violence, anti-government demonstration, death from political violence, and political strikes should be used in measuring political instability.

\section{References}

Arendt, H. (1951). The origins of totalitarianism. New York: Harcourt, Brace.

Caselli, F., \& Andrea, T. (2011). Resource Windfalls, Political Regimes, and Political Stability. NBER Working Paper No. 17601. http://dx.doi.org/10.3386/w17601

Davies, S. E. (2014). Healthy populations, political stability, and regime type: Southeast Asia as a case study. Review of International Studies, 40(5), 859-876. http://dx.doi.org/10.1017/ S0260210514000321

Di Palma, G. (1990). To craft democracies: an essay on democratic transitions. Berkeley: University of California Press.

Ekman, J. (2009). Political Participation and Regime Stability: A Framework for Analyzing Hybrid Regimes. International Political Science Review, 30(1), 7-31. http://dx.doi.org /10.1177/0192512108097054

Friedrich, C. J., \& Brzezinski, Z. K. (1965). Totalitarianism, dictatorship and autocracy. New York: Praeger.

Gasiorowski, M. J. (1990). The Political Regimes Project. Studies in Comparative International Development, 25(1), 109-125. http://dx.doi.org/10.1007/BF02716907

Gasiorowski, M. J., \& Timothy, J. P. (1998). The Structural Determinants of Democratic Consolidation. Comparative Political Studies, 31, 740-771. http://dx.doi.org/10.1177/001 0414098031006003

Gurr, T. R., Marshall, M. G., \& Khosla, Deepa (2001). Peace and Conflict 2001: A Global Survey of Armed Conflicts, Self-Determination Movements, and Democracy. Maryland: Center for International Development and Conflict Management, University of Maryland. 


\section{Macrothink}

Issues in Social Science ISSN 2329-521X 2015, Vol. 3, No. 2

Hadenius, A., \& Teorell, J. (2006). Authoritarian Regimes: stability, change, and pathways to democracy, 1972-2003. Working Paper 331, The Helen Kellogg Institute for International Studies. [Online] Available: https://kellogg.nd.edu/publications/workingpapers/WPS/331.pdf

Hanson, S. E., \& Kopstein, J. S. (2005). Regime Type and Diffusion in Comparative Politics Methodology. Canadian Journal of Political Science / Revue Canadienne de Science Politiqu, 38(1), 69-99.

Hewitt, J. J., Wilkenfeld, J., Gurr, T. R., \& Birger, H. (2012). Peace and Conflict 2012. Maryland: Center for International Development and Conflict Management, University of Maryland.

Hibbs, D, A, Jr. (1973). Mass political violence: a cross-national causal analysis. NY, London: John Willy \& Sons.

Huntington, S. P. (1968). Political Order in Changing Societies. New Haven: Yale University Press.

Lawrence, C. N. (2000). Regime Stability and Presidential Government: The Legacy of Authoritarian Rule, 1951-90. [Online] available: www.cnlawrence.com/papers/stability -review.pdf

Lerner, D (1958). The passing of traditional society. Illinois: Free Press.

Lijphart, A. (1977). Democracy in plural societies: a comparative exploration. New Haven: Yale University Press.

Lijphart, A. (1999). Patterns of democracy: government forms and performance in thirty-six countries. New Haven: Yale University Press.

Linz, J. J. (1987). The breakdown of democratic regimes: crisis, breakdown, \& reequalibrium. Baltimore: Johns Hopkins Univ. Press.

Linz, J. J. (1990a). The Perils of Presidentialism. Journal of Democracy, 1(1), 51-69.

Linz, J. J. (1990b). The Virtues of Parliamentarism. Journal of Democracy, 1(4), 84-91.

Mainwaring, S. (1993). Presidentialism, Multipartism, and Democracy: The Difficult Combination. Comparative Political Studies, 26(2), 198-228. http://dx.doi.org/10.1177 /0010414093026002003

Mainwaring, S., \& Shugart, M. S. (1997). Presidentialism and democracy in Latin America. Cambridge: Cambridge University Press.

Mainwaring, S., \& Timothy, R. S. (1995). Building democratic institutions: party systems in Latin America. Stanford, Calif: Stanford University Press.

Margolis, J. E. (2010). Understanding political stability and instability. Civil Wars, 12(3), 326-345.

Margolis, J. E. (2012). Estimating State Instability. Studies in Intelligence, 56(1), 13-24.

Marshall, M. G. (2008). Fragility, in stability, and the failure of states: assessing sources of systemic risk. New York: Carnegie Corporation.

O'Donnell, G. A. (1973). Modernization and bureaucratic authoritarianism: studies in south American politics. Berkley: University of California. 


\section{Macrothink}

Issues in Social Science ISSN 2329-521X 2015, Vol. 3, No. 2

Power, T. J., \& Gasiorowski, M. J. (1997). Institutional Design and Democratic Consolidation in the Third World. Comparative Political Studies, 30, 123-155. http://dx.doi.org/10.1177/0010414097030002001

Przeworski, A., \& Fernando, L. (1993). Political Regimes and Economic Growth. The Journal of Economic Perspectives, 7(3), 51-69. http://dx.doi.org/10.1257/jep.7.3.51

Przeworski, A., Michael, E. A., Jos`e, A. C., \& Fernando, L. (2000). Democracy and development: political institutions and well-being in the world, 1950-90. New York: Cambridge University Press.

Seifu, M. (2009). Determinants of regime survival in Africa. African Journal of Political Science and International Relations, 3(8),341-345.

Shugart, M. S., \& Carey, J. M. (1992). Presidents and assemblies: constitutional design and electoral dynamics. New York: Cambridge University Press.

Skaaning, S. -E. (2006). Political Regimes and Their Changes: A Conceptual Framework. Working papers (No. 55). Stanford: Center on Democracy, Development and the Rule of Law.

Snyder, R., \& Mahoney, J. (1999). The Missing Variable: Institutions and the Study of Regime Change. Comparative Politics, 32(1), 103-122. http://dx.doi.org/10.2307/422435

Sottilotta, C. E. (2013). Political Stability in Authoritarian Regimes: Lessons from the Arab Uprisings. IAI Working Papers 1301. [Online] Available: http://www.isn.ethz.ch /Digital-Library/Publications/Detail/?lng=en\&id=157647

Stepan, A. (1973). Authoritarian Brazil: origins, policies, and future. New Haven: Yale University Press.

Stepan, A., \& Skach, C. (1993). Constitutional Frameworks and Democratic Consolidation: Parliamentarianism versus Presidentialism. World Politics, 46, 1-22. http://dx.doi.org $/ 10.2307 / 2950664$ 